\title{
The Rare, Unexpected Condition of a Twisted Leiomyoma in Mayer-Rokitansky-Küster-Hauser (MRKH) Syndrome: Etiopathogenesis, Diagnosis and Management. Our Experience and Narrative Review of the Literature
}

\author{
Federico Romano ${ }^{1}$ (D), Stefania Carlucci ${ }^{2}$, Guglielmo Stabile ${ }^{1, *(\mathbb{D})}$, Giuseppe Mirenda ${ }^{3}$, Mariateresa Mirandola ${ }^{3}$, \\ Francesco Paolo Mangino ${ }^{1}$, Andrea Romano ${ }^{4}$ and Giuseppe Ricci ${ }^{1,3}$ (D)
}

1 Institute for Maternal and Child Health, I.R.C.C.S. "Burlo Garofolo", 34100 Trieste, Italy; federico.romano@burlo.trieste.it (F.R.); francesco.mangino@burlo.trieste.it (F.P.M.); giuseppe.ricci@burlo.trieste.it (G.R.)

2 Department of Obstetrics and Gynecology, Azienda Sanitaria Universitaria Giuliano-Isontina, San Polo Hospital, Gorizia-Monfalcone, 34127 Trieste, Italy; s.carlucci86@gmail.com

check for updates

Citation: Romano, F.; Carlucci, S.; Stabile, G.; Mirenda, G.; Mirandola,

M.; Mangino, F.P.; Romano, A.; Ricci,

G. The Rare, Unexpected Condition

of a Twisted Leiomyoma in

Mayer-Rokitansky-Küster-Hauser (MRKH) Syndrome:

Etiopathogenesis, Diagnosis and Management. Our Experience and Narrative Review of the Literature. Int. J. Environ. Res. Public Health 2021, 18, 5895. https://doi.org/10.3390/ ijerph18115895

Academic Editors: Milan Terzic,

Antonio Simone Laganà and

Antonio Sarria-Santamera

Received: 9 April 2021

Accepted: 26 May 2021

Published: 31 May 2021

Publisher's Note: MDPI stays neutral with regard to jurisdictional claims in published maps and institutional affiliations.

Copyright: (c) 2021 by the authors. Licensee MDPI, Basel, Switzerland. This article is an open access article distributed under the terms and conditions of the Creative Commons Attribution (CC BY) license (https:// creativecommons.org/licenses/by/ $4.0 /)$.
3 Clinical Department of Medical, Surgical and Health Sciences, University of Trieste, 34137 Trieste, Italy; giuseppe.mirenda@burlo.trieste.it (G.M.); tea.mirandola@gmail.com (M.M.)

4 UCO Pathological Anatomy and Histology, Azienda Ospedaliera-Universitaria Ospedali Riuniti, 34129 Trieste, Italy; andrea.romano@asuits.sanita.fvg.it

* Correspondence: guglielmost@gmail.com

\begin{abstract}
Uterine leiomyomas are a common finding in medical practice, but their frequency changes drastically when contextualized in a syndrome, as in the following case. A 50-year-old woman with a known Mayer-Rokitansky-Küster-Hauser (MRKH) syndrome presented at our clinic with abdominal pain located in the lower quadrants and scarcely responsive to analgesic therapy. A twisted gynecological pelvic mass was diagnosed, and management for prompt resolution was adopted. Histologically the mass was described as a leiomyoma. The aim of the present study is to share our experience and to review the literature to compare different manifestation of the disease and different approach used in the various centers. The additional novelty of the paper is the immunohistochemical study we carried out on the leiomyoma that is contrasted with the current etiopathogenetic theories.
\end{abstract}

Keywords: Mayer-Rokitansky-Küster-Hauser; leiomyoma; pelvic mass; torsion

\section{Introduction}

Mayer-Rokitansky-Küster-Hauser (MRKH) syndrome is one of the most common causes of primary amenorrhea, second only to gonadic dysgenesis, having a frequency of 1:4000-5000 women [1]. This syndrome manifests as an aplasia or hypoplasia of the uterus and the upper two-thirds of the vagina, regular ovaries and tubes and a normal development of secondary sexual characteristics [2]. The karyotype is generally normal $(46, X X)$ and the manifestation is secondary to an abnormal development of the müllerian ducts.

The syndrome has three different forms: type 1, typical form, is characterized by congenital absence of the uterus and the upper two-thirds of the vagina with regular adnexa; type 2, atypical form, manifests alterations to the genital apparatus (ovaries) and renal defects; type 3 shows aplasia or hypoplasia of the uterus and vagina in association with renal malformations (ectopic kidney, renal agenesis, horseshoe kidney) as well as skeleton, cardiac, ocular and hearing alterations, known as MURC syndrome [3]. In the past, the syndrome has been considered as a sporadic anomaly, but the increasing number of familial cases supports the hypothesis of a genetic cause. In these cases, the syndrome 
appears to be transmitted as an autosomal dominant trait with incomplete penetrance and variable expressivity. However, the etiology of MRKH syndrome remains unclear.

The presence of leiomyomas in patients with MRKH syndrome is rare and, according to a recent review, only one other case has been described in Italy [4]. The majority of leiomyomas develop in women with a mono or bilateral rudimental uterus; in the literature, a leiomyoma in the absence of a rudimental uterus is described only in two cases. Diagnostic imaging may not give an unequivocal interpretation. In some cases, CT scans, as well as MRI, are not accurate in the diagnosis of leiomyoma or its anatomical delineation $[5,6]$. Therefore, in most cases, surgery is the only diagnostic tool to define the nature of the lesion.

Leiomyomas are benign tumors derived from smooth muscle cells forming the myometrium. They represent the most common benign female genital neoplasia with an estimated frequency of $20 \%$ of the population between 30 - and 60 -year-old women [7]. In the current study, we would like to describe the case of a 50 year old patient with MRKH syndrome who was hospitalized with acute abdomen due to intraoperative evidence of a para-ovarian pelvic neoformation twisted on its own peduncles. Furthermore, the purpose of this study is to identify the number of cases of leyomyomas in patients with MRKH reported in the literature and how many of these manifested as an acute abdomen. Secondly, in these selective cases, we wanted to evaluate and compare the surgical approaches adopted. In addition, we analyzed the immunohistochemical aspect of the leiomyoma.

\section{Case}

A 50-year-old woman presented in the emergency room who had been experiencing abdominal pain for one week. Initially the pain was spread throughout the abdomen and was similar to cramps; later on, it started to be confined and localized in the abdominal inferior quadrants and was scarcely responsive to an analgesic therapy. There were no accompanying symptoms or increased inflammatory markers. The patient was aware of being affected by MRKH syndrome, which was diagnosed in puberty during a follow-up for a primary amenorrhea. The patient was also aware of a pelvic mass of unknown origin discovered 5 years prior during a routine ultrasound. During the anamnesis, the patient denied having menstrual flows and pelvic pains in the past.

At the medical examination, the abdomen was soft and non-tender except for a strong tenderness corresponding to a hardened hypogastric tumefaction. The Blumberg sign was negative. Blood tests were requested and came out normal. White blood count and $C$ reactive protein were negative. An abdominal ultrasound was performed as well as a computed tomography, with identification of both kidneys, normal in size and position, with smooth profiles and a regular echogenicity and parenchymal thickness, without any signs of cystic alterations in their context. There was no sign of hydronephrosis on the right side; mild pyelectasis was found on the left kidney. The bladder was expanded with regular walls. A neoformation of unknown origin was identified in the pelvic region described as a voluminous pelvic expansive formation (major transverse diameter: $9 \mathrm{~cm}$; antero-posterior diameter: $11 \mathrm{~cm}$ ) likely referred to a voluminous uterine partially calcified leiomyoma. Mild perihepatic and perisplenic effusion were also detected; liver, pancreas, spleen, adrenal glands and kidneys were normal.

At the gynecologic examination, the vagina was atresic, and a hard hypomobile tumefaction was identified in the pelvic region with its extension reaching $2 \mathrm{~cm}$ above the transverse umbilical line.

At transrectal and transvaginal ultrasonography examination (Voluson GE-E10; TV probe $5-9 \mathrm{MHz}$ and TA probe $1-5 \mathrm{MHz}$ ), the uterus was not recognizable nor was the endometrium visible, and the whole pelvis was occupied by a $15 \mathrm{~cm}$ diameter solid bilobate "C-shape" well-defined lesion (Figure 1) with mixed echogenicity as listed below: intense internal shadows with calcifications, material of ground-glass appearance surrounded by a hyperechogenic rim, peripheral moderate vascularization (color score 2) with no translesional vascularity, as described by MUSA terminology [8]. 
In addition, we described a ureterocele image in the left kidney, possibly due to extrinsic compression by the pelvic malformation or by primary renal malformation, as described in MRKH disease. Moderate peritoneal effusion was present in the pelvis.

Due to the worsening of the pain and no response to the analgesic therapy, a surgical approach was chosen, with a supposed diagnosis of an unknown origin pelvic lesion in a patient with MRKH syndrome. An initial laparoscopic approach was undertaken with the insertion of an umbilical $10 \mathrm{~mm}$ optical trocar and three $5 \mathrm{~mm}$ ancillary trocars. A rudimental uterus was highlighted on the right side of the pelvis with bilateral regular ovaries. A 15-cm dark-red left formation was found, departing from the rudimental uterus and twisted on its peduncle (Figure 2).

Considering the size and hardness of the mass due to calcifications present in its context, as well as the uncertain histologic nature of the mass, we decided to convert the surgery from laparoscopy to laparotomy by a transverse suprapubic mini-laparotomy. A small quantity of peritoneal liquid was drained and sent for cytological evaluation. After identification of the left ureter by retroperitoneal access, we proceeded with the removal of the entire mass with its vascular peduncle.

The mass (Figure 3) was, therefore, sent for histological evaluation. The diagnosis was a spindle-cell neoplasia, partially ossified, with sclero-hyaline areas characterized by hemorrhagic centers and a lumpy and congested area, measuring $10 \mathrm{~cm} \times 9 \mathrm{~cm} \times 7 \mathrm{~cm}$ and weighing $460 \mathrm{~g}$ with a fibroadipose congested extension measuring $10 \mathrm{~cm} \times 5 \mathrm{~cm} \times 3 \mathrm{~cm}$; the morphologic and immunohistochemical findings are coherent with hemorrhagic sclerohyaline leiomyoma, possibly caused by a torsion (Figures 4-6). Moreover, the immunohistochemical analysis was negative for the presence of progestin and estrogenic receptors.

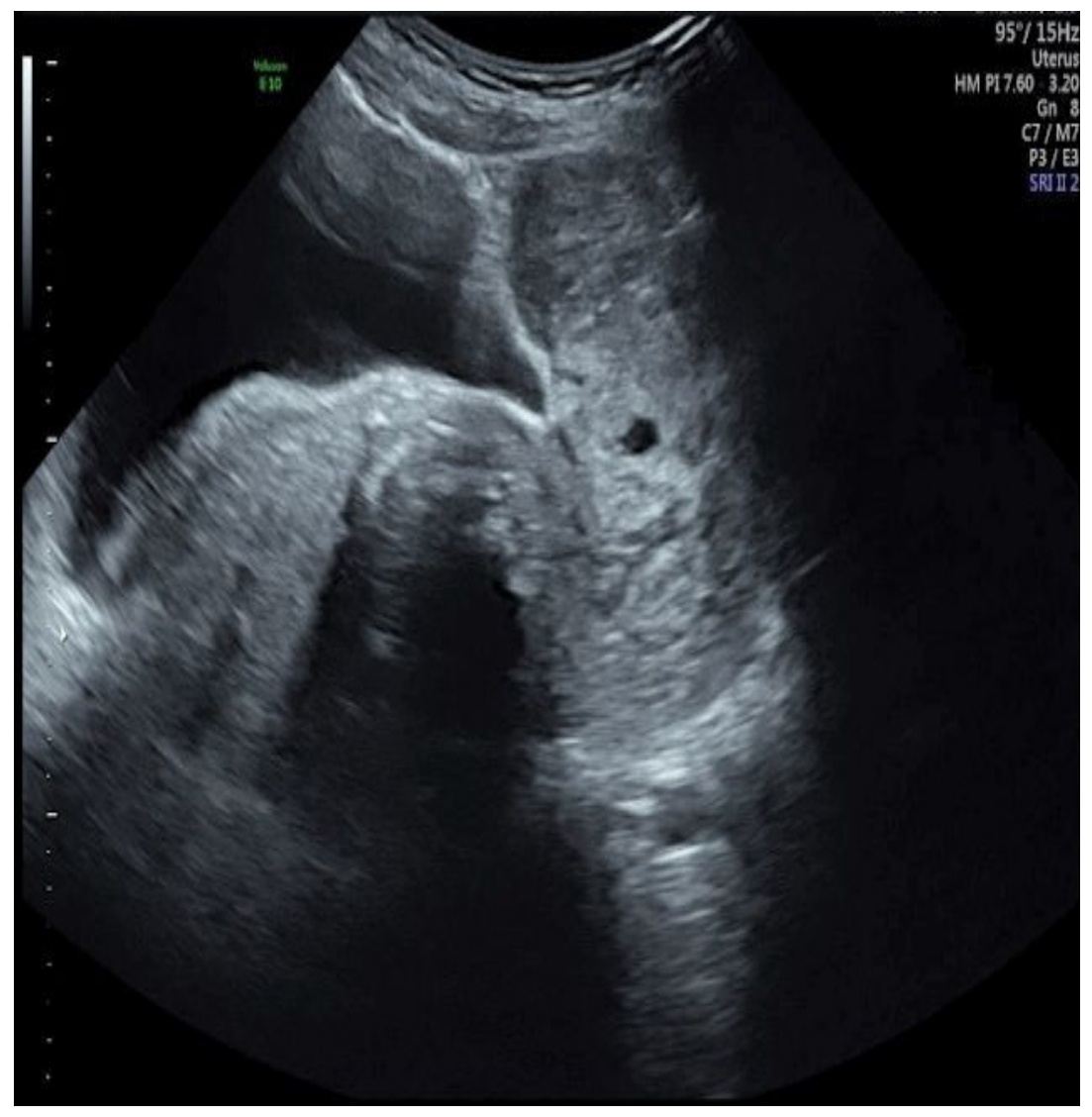

Figure 1. Ultrasound image of the lesion. 


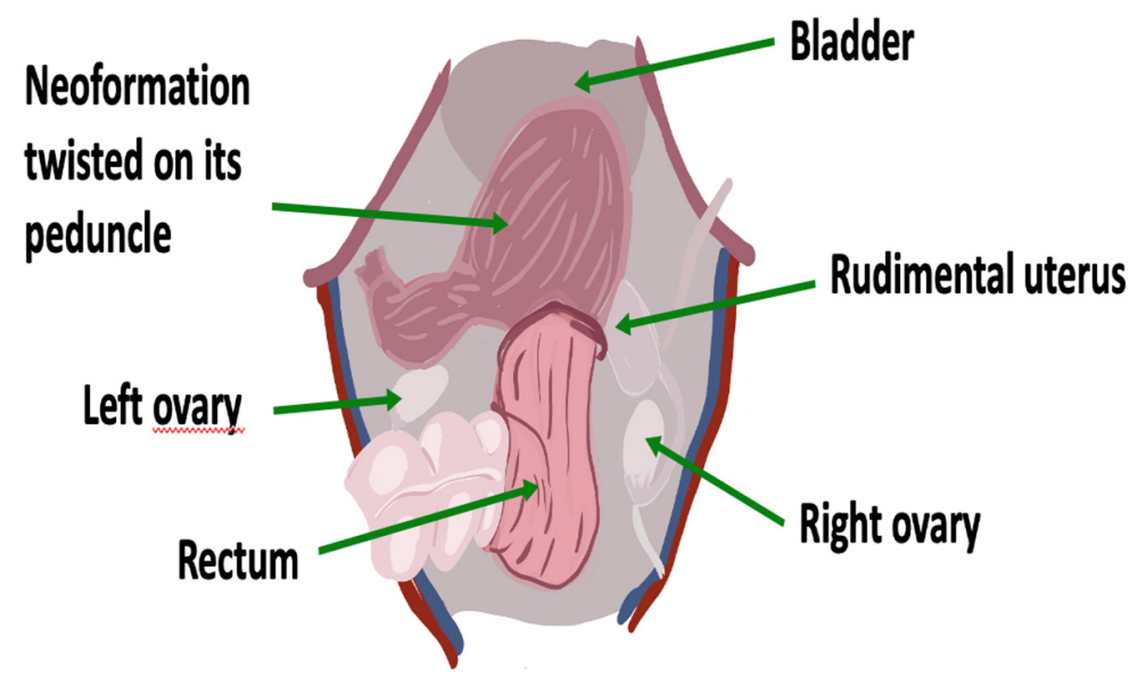

Figure 2. Anatomical relationships of the rudimentary uterus and of the neoformation inside the pelvis.

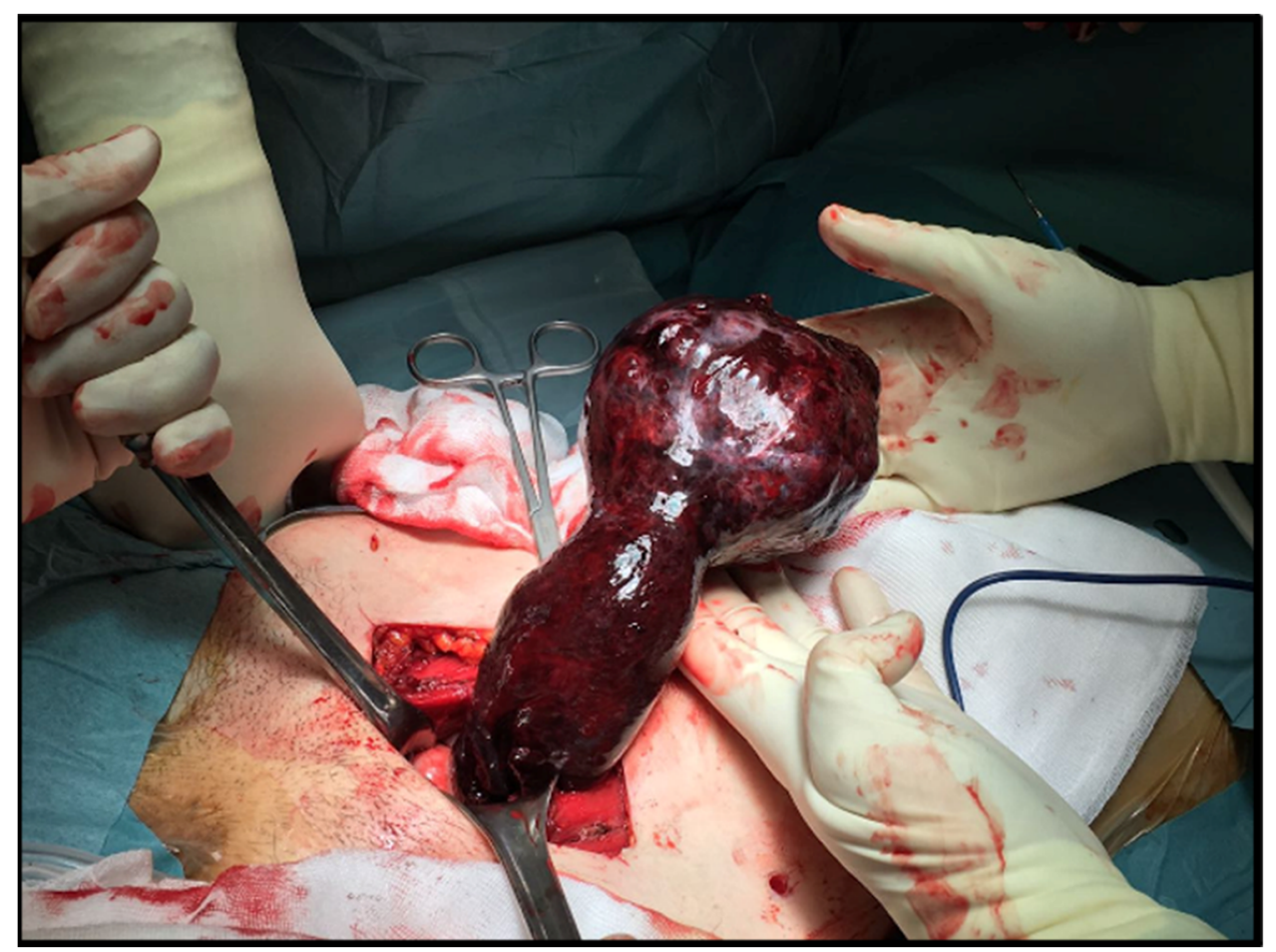

Figure 3. Leiomyoma twisted on its peduncle outside the abdomen. 


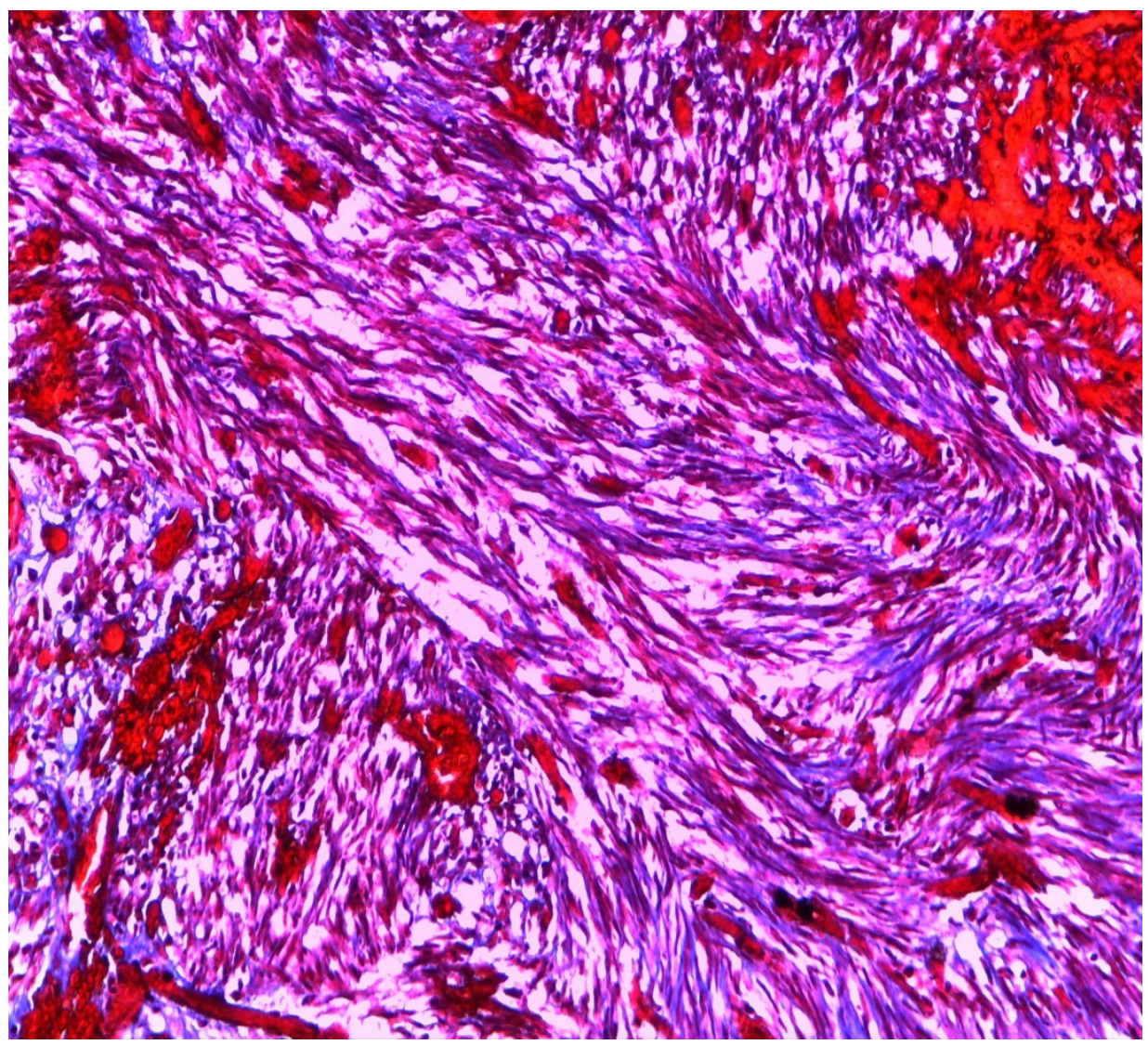

Figure 4. Histological image of leiomyoma stained with Trichrome-Masson.

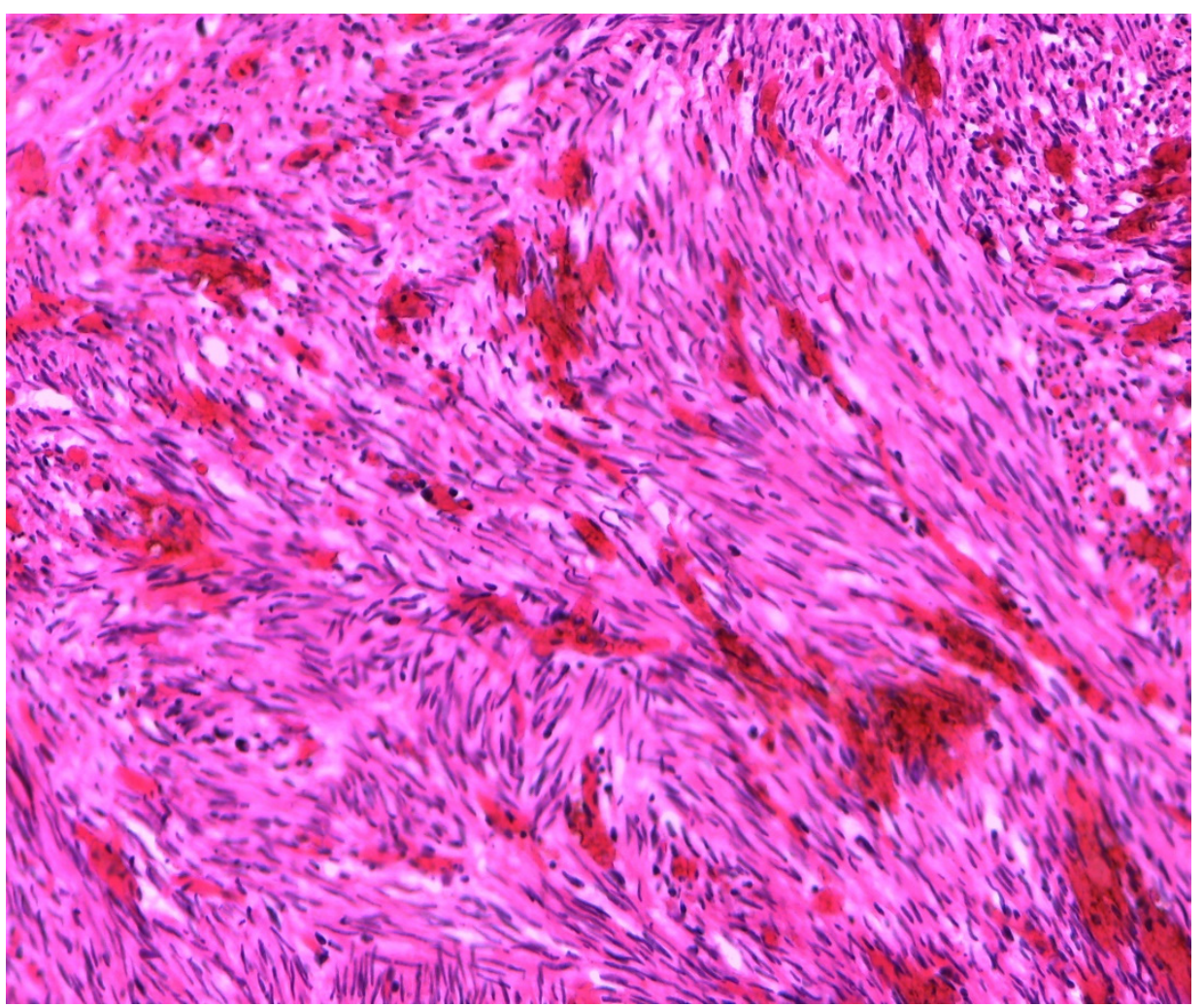

Figure 5. Histological image of leiomyoma stained with hematoxylin. 


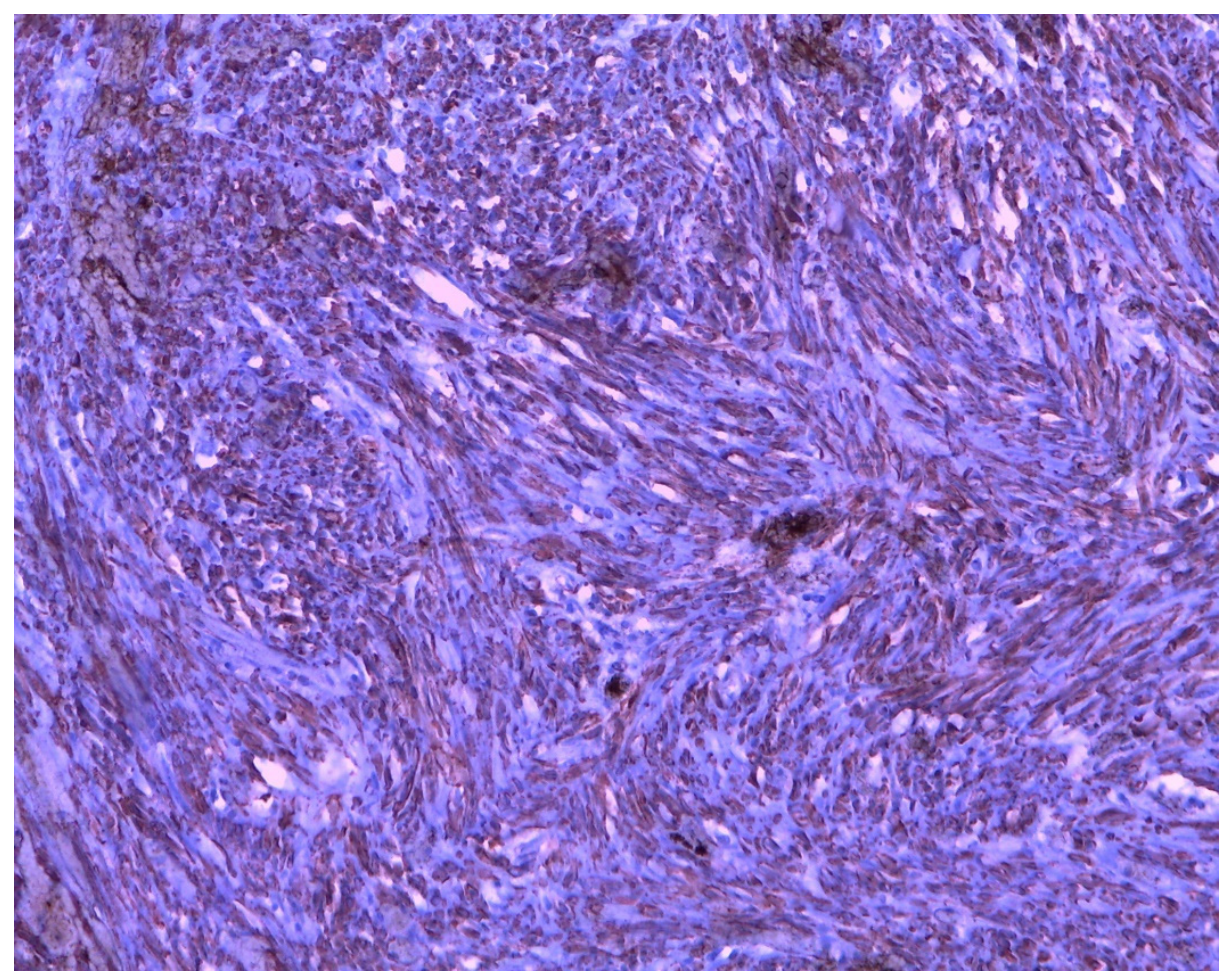

Figure 6. Histological image of leiomyoma with smooth muscle actin stain.

\section{Materials and Methods}

A search was carried out on PubMed and Scopus (until December 2020) to identify articles involving patients with MRKH and leiomyomatosis. The manuscripts considered were published from 1999. The research was focused on original articles in English. Nine manuscripts were detected through the references of the works that had been identified with the research on PubMed and Scopus. A total of 35 cases were found describing the presence of myomatosis in patients with MRKH where 27 were not complicated and 8 , instead, had an acute manifestation similar to our case.

\section{Results}

Apparently, there are only 27 cases described of uterine leiomyoma in MRKH not complicated by acute abdomen (Table 1) [2-4,9-31]. The average age at the time of diagnosis was 41.8 years. The cases described have been evaluated for patients undergoing routine examination or urgent assessment due to chronic symptomatology, not for acute pain, as in our case. The preferred surgical approach is laparotomy; in only four cases the mass has been removed in laparoscopy. In almost all cases, the lesion originated from a rudimental uterine horn and apparently in only three cases, it was not.

Focusing our attention on cases with acute onset similarly to ours, we found only eight cases where a torsion of the lesion was described [5,6,31-37]. In six cases, the clinical manifestation was an acute abdomen and, apparently, only in two cases, the torsion concerned only the mass and not the annexes.

To better understand the manifestation of the disease and the different management of it worldwide, we proceeded to analyze a few features, as follows. In almost all cases, the first suspicion was given by ultrasound since it is the faster instrument used in the emergency room. After that, magnetic resonance and computed tomography were used to confirm the diagnosis.

The average age of onset of the disease was 45.5 years old, ranging from 28 to 55 years old and in line with the typical age of leiomyoma manifestation. The volume of the masses is similar in almost all cases, around $10 \mathrm{~cm} \times 15 \mathrm{~cm}$. Only in one case, the dimension of 
the pelvic mass was smaller, and in two studies, there is no mention of the volume of the myomas. The mass origin was from a rudimentary uterus in four cases, paraovarian or adnexal in three cases and not clarified in the remanent two cases. Regarding the surgical approach, all the surgeons preferred laparotomy access with respect to a laparoscopic one, with the only exception of Yi et al. [34] who, unfortunately, did not report the dimension of the lesion; therefore, an analysis of their choice is not possible. Finally, four out of nine surgeons removed the twisted mass only, whereas the others chose the removal of the rudimental uterus.

Table 1. Cases of uterine leiomyomas in Mayer-Rokitansky-Küster-Hauser (MRKH) syndrome.

\begin{tabular}{|c|c|c|c|c|c|c|c|c|}
\hline \multicolumn{9}{|c|}{ MRKH Syndrome and Myomatosis } \\
\hline Case & Authors & Nationality & $\begin{array}{l}\text { Age of } \\
\text { Patients }\end{array}$ & Symptoms & Imaging & Location & Dimensions & $\begin{array}{l}\text { Tipe of } \\
\text { Surgery }\end{array}$ \\
\hline 1 & $\begin{array}{c}\text { Rhee } \\
\text { Abdom. Imaging } \\
1999 \text { [27] }\end{array}$ & Korea & 49 & None & MRI & $\begin{array}{l}\text { Rudimentary } \\
\text { uterus }\end{array}$ & $\begin{array}{c}10 \mathrm{~cm} \times 10 \mathrm{~cm} \times 6 \\
\mathrm{~cm}\end{array}$ & LPS \\
\hline 2 & $\begin{array}{c}\text { Tsin } \\
\text { J. Am. Assoc. } \\
\text { Gynecol. Laparosc. } \\
2000[28]\end{array}$ & USA & 36 & None & $\mathrm{US}+\mathrm{CT}$ & - & $8.4 \mathrm{~cm}$ & LPS \\
\hline 3 & $\begin{array}{l}\text { Endemonds } \\
\text { J. Pediatr. Adolesc. } \\
\text { Gynecol. } 2003 \text { [17] }\end{array}$ & England & 70 & $\begin{array}{c}\text { Abdominal } \\
\text { swelling -nocturia }\end{array}$ & - & - & $10 \mathrm{~cm}$ & LPT \\
\hline 4 & $\begin{array}{l}\text { Jadoul } \\
\text { Fertil. Steril. } 2004 \text { [15] }\end{array}$ & Belgium & 42 & Dyspareunia & US-MRI & $\begin{array}{l}\text { Left rudimentary } \\
\text { uterus }\end{array}$ & $10 \mathrm{~cm}$ & LPS \\
\hline 5 & $\begin{array}{c}\text { Deligeoroglu } \\
\text { Fertil. Steril. } 2004 \text { [20] }\end{array}$ & Greece & $\begin{array}{l}\text { Case I } 42 \\
\text { Case II } 38\end{array}$ & $\begin{array}{l}\text { Case I: chronic pain } \\
\text { Case II: } \\
\text { None }\end{array}$ & US & $\begin{array}{l}\text { Rudimentary } \\
\text { uterus }\end{array}$ & $\begin{array}{c}\text { Case I: } 5.9 \mathrm{~cm} \times 5.5 \\
\mathrm{~cm} \\
\text { Case II: } 5.8 \mathrm{~cm} \times \\
9.6 \mathrm{~cm}\end{array}$ & LPS \\
\hline 6 & $\begin{array}{c}\text { Papa } \\
\text { Fertil. Steril. } 2008 \text { [4] }\end{array}$ & Italy & 47 & Chronic pain & US + MRI & Retrovescical space & $15 \mathrm{~cm}$ & LPS \\
\hline 7 & $\begin{array}{l}\text { Lamarca } \\
\text { Fertil. Steril. } 2009 \text { [18] }\end{array}$ & Spain & 35 & Infertility & US-MRI & $\begin{array}{c}\text { Rudimentary } \\
\text { uterus }\end{array}$ & $3-5 \mathrm{~cm}$ & LPT \\
\hline 8 & $\begin{array}{l}\text { Lanowska } \\
\text { Fertil. Steril. } 2009 \text { [26] }\end{array}$ & Germany & 39 & None & US + MRI & $\begin{array}{l}\text { Rudimentary } \\
\text { uterus }\end{array}$ & 8.5 & LPS \\
\hline 9 & $\begin{array}{c}\text { Pati } \\
\text { J. Indian Med. Assoc. } \\
2009[31]\end{array}$ & India & 20 & $\begin{array}{c}\text { Primary } \\
\text { amenorrhea } \\
\text { Chronic pain }\end{array}$ & - & $\begin{array}{l}\text { Rudimentary } \\
\text { uterus }\end{array}$ & $8 \mathrm{~cm} \times 7 \mathrm{~cm}$ & LPT \\
\hline 10 & $\begin{array}{c}\text { Fukuda } \\
\text { J. Obstet. Gynaecol. } \\
\text { Res 2010 [29] }\end{array}$ & Japan & 50 & Chronic pain & $\mathrm{CT}+\mathrm{MRI}$ & $\begin{array}{l}\text { Rudimentary } \\
\text { uterus }\end{array}$ & $7 \mathrm{~cm}$ & LPT \\
\hline 11 & $\begin{array}{c}\text { Chun } \\
\text { J. Menopausal Med. } \\
2013[14]\end{array}$ & Korea & 55 & None & MRI & $\begin{array}{l}\text { Rudimentary } \\
\text { uterus }\end{array}$ & $\begin{array}{c}5.4 \mathrm{~cm} \times 4.8 \mathrm{~cm} \times \\
4.7 \mathrm{~cm}\end{array}$ & LPT \\
\hline 12 & $\begin{array}{c}\text { Pàez Lòpez } \\
\text { Rev. Colomb. Obstet. } \\
\text { Ginecol. } 2013 \text { [16] }\end{array}$ & Colombia & 32 & Chronic pain & US & $\begin{array}{l}\text { Rudimentary } \\
\text { uterus }\end{array}$ & $9 \mathrm{~cm}$ & LPS \\
\hline 13 & $\begin{array}{c}\text { Rawat } \\
\text { J. Radiol. Case Rep. } \\
2013 \text { [19] }\end{array}$ & India & 35 & None & US-CT-MRI & $\begin{array}{l}\text { Rudimentary } \\
\text { uterus }\end{array}$ & $\begin{array}{c}25 \mathrm{~cm} \times 18 \mathrm{~cm} \times \\
12 \mathrm{~cm}\end{array}$ & LPT \\
\hline 14 & $\begin{array}{c}\text { Kulkarni } \\
\text { J. Hum. Reprod. Sci. } \\
2015 \text { [21] }\end{array}$ & India & 25 & $\begin{array}{c}\text { Primary } \\
\text { amenorrhea }\end{array}$ & US-MRI & $\begin{array}{l}\text { Rudimentary } \\
\text { uterus }\end{array}$ & $\begin{array}{c}5 \mathrm{~cm} \times 4 \mathrm{~cm} \times 4 \\
\mathrm{~cm}\end{array}$ & LPT \\
\hline 15 & $\begin{array}{c}\text { Girma } \\
\text { Ethiop. J. Health Sci. } \\
2015 \text { [22] }\end{array}$ & Ethiopia & 40 & Chronic pain & US & $\begin{array}{l}\text { Right broad } \\
\text { ligament and right } \\
\text { Mullerian bulb }\end{array}$ & $\begin{array}{c}18 \mathrm{~cm} \times 10 \mathrm{~cm} \times 8 \\
\mathrm{~cm}\end{array}$ & LPT \\
\hline 16 & $\begin{array}{c}\text { Narayanan } \\
\text { BMJ Case Rep. } 2015 \\
{[11]}\end{array}$ & India & 43 & Chronic pain & US + MRI & $\begin{array}{l}\text { Rudimentary } \\
\text { uterus }\end{array}$ & - & LPT \\
\hline 17 & $\begin{array}{c}\text { Hasegawa } \\
\text { Obstet. Gynecol. } 2015 \\
{[13]}\end{array}$ & Japan & 40 & $\begin{array}{l}\text { Abdominal } \\
\text { swelling }\end{array}$ & $\begin{array}{c}\mathrm{US}+\mathrm{MRI}+ \\
\mathrm{CT}\end{array}$ & $\begin{array}{l}\text { Rudimentary } \\
\text { uterus }\end{array}$ & $20 \mathrm{~cm} \times 30 \mathrm{~cm}$ & LPT \\
\hline 18 & $\begin{array}{c}\text { Park } \\
\text { J. Obstet. Gynaecol. } \\
2016 \text { [12] }\end{array}$ & Korea & 36 & None & $\mathrm{CT}$ & $\begin{array}{l}\text { Rudimentary } \\
\text { uterus }\end{array}$ & $16 \mathrm{~cm} \times 92 \mathrm{~cm}$ & LPT \\
\hline
\end{tabular}


Table 1. Cont.

\begin{tabular}{|c|c|c|c|c|c|c|c|c|}
\hline \multicolumn{9}{|c|}{ MRKH Syndrome and Myomatosis } \\
\hline Case & Authors & Nationality & $\begin{array}{c}\text { Age of } \\
\text { Patients }\end{array}$ & Symptoms & Imaging & Location & Dimensions & $\begin{array}{l}\text { Tipe of } \\
\text { Surgery }\end{array}$ \\
\hline 19 & $\begin{array}{l}\quad \text { Salem } \\
\text { Facts Views Vis. } \\
\text { Obgyn. 2016 [2] }\end{array}$ & Iraq & 40 & None & US & $\begin{array}{l}\text { Right-sides } \\
\text { intra-peritoneal } \\
\text { space of round } \\
\text { ligament }\end{array}$ & $7 \mathrm{~cm} \times 9 \mathrm{~cm}$ & $\mathrm{LPT}$ \\
\hline 20 & $\begin{array}{c}\text { Dimitriadis } \\
\text { J. Reprod. Med. } 2016 \\
\text { [23] }\end{array}$ & USA & 43 & None & - & - & - & LPS+LPT \\
\hline 21 & $\begin{array}{c}\text { Amaratunga } \\
\text { Ultrasound Quarterly } \\
2017[3]\end{array}$ & Canada & 66 & Chronic pain & US + MRI & Right annexed area & $4.5 \mathrm{~cm} \times 4 \mathrm{~cm}$ & LPS \\
\hline 22 & $\begin{array}{c}\text { Sharma } \\
\text { Int. J. Gynaecol. } \\
\text { Obstet. } 2017 \text { [10] }\end{array}$ & India & 45 & Chronic pain & $\mathrm{US}+\mathrm{CT}$ & $\begin{array}{l}\text { Right and left } \\
\text { rudimentary horn }\end{array}$ & $\begin{array}{c}18 \mathrm{~cm} \times 15 \mathrm{~cm} ; 5 \\
\mathrm{~cm} \times 4 \mathrm{~cm}\end{array}$ & LPT \\
\hline 23 & $\begin{array}{c}\text { Karthik } \\
\text { J. Gynecol. Surg. } 2017 \\
{[24]}\end{array}$ & India & 33 & $\begin{array}{c}\text { Primary } \\
\text { amenorrhea } \\
\text { Dyspareunia }\end{array}$ & US-MRI & $\begin{array}{l}\text { Rudimentary } \\
\text { uterus }\end{array}$ & $7.6 \mathrm{~cm} \times 5.3 \mathrm{~cm}$ & LPS \\
\hline 24 & $\begin{array}{c}\text { Albahlol } \\
\text { Eur. J. Obstet. } \\
\text { Gynecol. } 2019 \text { [30] }\end{array}$ & Egypt & 45 & $\begin{array}{c}\text { Primary } \\
\text { amenorrhea } \\
\text { Dyspareunia }\end{array}$ & $\mathrm{US}+\mathrm{MRI}$ & - & $15 \mathrm{~cm} \times 12 \mathrm{~cm}$ & LPT \\
\hline 25 & $\begin{array}{c}\text { Jokimma } \\
\text { BMC Women's } \\
\text { Health } 2020 \text { [9] }\end{array}$ & Finland & 47 & None & US-MRI & - & $6 \mathrm{~cm}$ & - \\
\hline 26 & $\begin{array}{c}\text { Harzif } \\
\text { Int. J. Surg. Case Rep. } \\
2021 \text { [25] }\end{array}$ & Indonesia & 38 & Chronic pain & US + MRI & $\begin{array}{l}\text { Rudimentary } \\
\text { uterus }\end{array}$ & $\begin{array}{l}6 \mathrm{~cm} \\
5 \mathrm{~cm}\end{array}$ & LPS \\
\hline
\end{tabular}

\section{Discussion}

The presence of a pelvic mass in a woman with MRKH can be a diagnostic dilemma due to a subverted gynecologic anatomy and the frequent association with renal malformations. The low incidence of the disease makes the diagnosis even more difficult. Our experience and a review of the literature demonstrate that leiomyomas may develop in the context of a rudimental uterus, but it is a rare finding. Specifically, our case falls within the classic form of the syndrome, with the presence of a rudimental unilateral uterus. Clinically, it seems that the mass can be completely asymptomatic until its volume reaches great dimensions $(10-15 \mathrm{~cm})$. Larger or smaller myomas, generally, do not lead to an acute complication. This is probably due to the poor mobility and, therefore, to the reduced possibility of torsion of myomas of these sizes.

The age of onset is the same of the population with normal gynecologic development, and surgeons almost unanimously prefer the laparotomic approach in emergency cases such as the ones analyzed in the current review.

On ultrasound examination, leiomyomas are hypoechoic or heterogeneous masses. Sometimes there can be an internal cystic degeneration with necrosis or hemorrhage that appears ultrasonographically as a cystic component with internal echogenic material; differently, calcifications appear as hyperechoic foci [22].

The pre-surgical differential diagnosis between an ovarian lesion and a lesion of a rudimental uterus may be difficult since the usual anatomical landmarks are subverted. For example, a large pelvic mass with possible inner myxomatous degeneration may be easily confused with a cystic ovarian lesion [11].

If the mass is associated with pelvic pain, adenomyosis and other pathologies should be considered in the differential diagnosis, as described in rare cases [35,38]. In our case, the patient denied a history of pelvic pain, endometriosis and she declared that she never had a menstrual cycle. This excluded from the differential diagnosis the possibility of hematocolpos or pain related to the hormonal cycle.

Among the few cases described in the literature, apparently only eight are reported to be the manifestation of the lesion as a twisted mass, and six patients had an acute abdomen. Furthermore, only in two reports, the torsion involved the mass exclusively, 
sparing the adnexa [5,6], similarly to what happened in our case (Table 2), where both surgical procedure and histological examination highlighted that neither the uterus or ipsilateral Fallopian tube were involved in the torsion. This allowed us to save the ovaries, preserving the hormonal balance of the patient. Apparently, this is the second case in which it was possible to spare the patient's ovaries.

Regarding the surgical procedure, the literature describes various approaches. Laparoscopic, as well as laparotomic techniques, have been chosen according to the patient's clinical evaluation, imaging, number of masses, mass localization and characteristics (size of the mass or complicated nature of its feeding arteries). Removing the remnant uterus may be a choice in order to prevent the risk of recurrence [21,32] and a mono or bilateral salpingo-oophorectomy may be added to the procedure, according to the mass location or complication [33]. In conclusion, even if our case seems to be clinically similar to a few others described in the literature, in the current paper, we would like to share a particular immunohistochemical aspect we have discovered.

In our review, only one case is described as a mitotically active leiomyoma [23], and the etiopathogenesis remains unclear. The current knowledge about it suggests that the pathogenesis of fibroids is a multistep process, starting with the recruitment of a smooth muscle stem cell from the myometrium that lacks receptors for the gonadal steroids. However, under the influence of specific driver mutations, in addition to estrogen, progesterone and WNT- $\beta$-catenin signaling, the stem cell differentiates into a preclinical fibroid. Subsequently, four key cell types that comprise fibroids (smooth muscle cells, vascular smooth muscle cells, fibroblasts and fibroid-associated fibroblasts) and the extracellular matrix (ECM) synergize with environmental and molecular stimuli to undergo growth acceleration and progression into clinical disease [39,40]. Therefore, the development of fibroids in an MRKH patient can be explained by the presence of smooth muscle cells in the proximal ends of the müllerian ducts, stimulated by the estrogen physiologically produced by the ovaries, resulting in the formation of leiomyomas; in these cells, the estrogenic receptors seem to be overexpressed [3]. However, Sharma et al. attribute low concentration or sensibility to the estrogenic stimulation by the receptors located on the rudimental uterine horns in women with MRKH [10]. Unfortunately, due to the worsening pain and urgent surgery, it was not possible to administer a perioperative hormonal dosage to our patient. However, a receptors study conducted over the mass removed from the patient presented quite a curios result. The presence of estrogenic and progestin receptors was negative (Figures 7 and 8). Therefore, our finding, in contrast with what some authors demonstrated in the past [41], reinforces the doubts about the etiopathogenesis of fibroids both in MRKH patients and in the general population. A potential bias in this case could be the ischemic condition caused by the torsion of the mass that could lead to a partial alteration of the tissues.

Table 2. Torsion of leiomyomas in Mayer-Rokitansky-Küster-Hauser (MRKH) syndrome in the literature.

\begin{tabular}{|c|c|c|c|c|c|c|c|}
\hline References & $\begin{array}{l}\text { Age of } \\
\text { Onset }\end{array}$ & $\begin{array}{c}\text { Acute } \\
\text { Abdomen }\end{array}$ & $\begin{array}{l}\text { Surgical } \\
\text { Approach }\end{array}$ & Imaging & $\begin{array}{l}\text { Dimension } \\
\text { of the Lesion }\end{array}$ & $\begin{array}{c}\text { Mass } \\
\text { Localization }\end{array}$ & Type of Surgery \\
\hline $\begin{array}{l}\text { YAN, et al. (2002) } \\
\text { [6] }\end{array}$ & 52 & Yes & LPT & $\mathrm{US}+\mathrm{CT}$ & $15 \mathrm{~cm}$ & $\begin{array}{l}\text { Rudimentary } \\
\text { uterus }\end{array}$ & $\begin{array}{l}\text { Hysterectomy and bilateral } \\
\text { salpingo-oophorectomy }\end{array}$ \\
\hline $\begin{array}{l}\text { Galajova, et al. } \\
\text { (2003) [37] }\end{array}$ & 55 & No & LPT & US & $10 \mathrm{~cm} \times 7.5 \mathrm{~cm}$ & Not reported & Mass only \\
\hline $\begin{array}{l}\text { Petric, et al. } \\
\text { (2008) [36] }\end{array}$ & 53 & Yes & LPT & Not reported & $\begin{array}{l}\text { Date not } \\
\text { available }\end{array}$ & Not clear origin & Mass only \\
\hline $\begin{array}{l}\text { FLETCHER, et al. } \\
\text { (2012) [5] }\end{array}$ & 28 & Yes & $\begin{array}{c}\text { LPT } \\
\text { Pfannenstiel }\end{array}$ & MRI & $10 \mathrm{~cm} \times 15 \mathrm{~cm}$ & $\begin{array}{l}\text { Paraovarian } \\
\text { mass }\end{array}$ & Mass only \\
\hline $\begin{array}{l}\text { VIDYASHREE, } \\
\text { et al. (2014) [32] }\end{array}$ & 40 & No & LPT & $\mathrm{CT}+\mathrm{MRI}$ & $\begin{array}{c}6 \mathrm{~cm} \times 7 \mathrm{~cm} \text { and } \\
5 \times 6 \mathrm{~cm}\end{array}$ & $\begin{array}{l}\text { Rudimental } \\
\text { uterus }\end{array}$ & $\begin{array}{l}\text { Bilateral salpingo-oophorectomy } \\
\text { and excision of uterine remnant }\end{array}$ \\
\hline $\begin{array}{l}\text { KUNDU, et al. } \\
\text { (2014) [33] }\end{array}$ & 40 & Yes & Vertical LPT & $\mathrm{US}+\mathrm{CT}$ & $10 \mathrm{~cm}$ & $\begin{array}{l}\text { Rudimentary } \\
\text { uterus }\end{array}$ & $\begin{array}{l}\text { Right salpingo-oophorectomy, } \\
\text { excision of right and left hemiuteri } \\
\text { with pedunculated leiomyomas, } \\
\text { and left salpingectomy }\end{array}$ \\
\hline
\end{tabular}


Table 2. Cont.

\begin{tabular}{|c|c|c|c|c|c|c|c|}
\hline References & $\begin{array}{l}\text { Age of } \\
\text { Onset }\end{array}$ & $\begin{array}{l}\text { Acute } \\
\text { Abdomen }\end{array}$ & $\begin{array}{l}\text { Surgical } \\
\text { Approach }\end{array}$ & Imaging & $\begin{array}{l}\text { Dimension } \\
\text { of the Lesion }\end{array}$ & $\begin{array}{c}\text { Mass } \\
\text { Localization }\end{array}$ & Type of Surgery \\
\hline $\begin{array}{l}\text { YI, et al. (2016) } \\
\text { [34] }\end{array}$ & 47 & Yes & LPS & MRI & $\begin{array}{l}\text { Date not } \\
\text { available }\end{array}$ & $\begin{array}{l}\text { Rudimentary } \\
\text { uterus }\end{array}$ & $\begin{array}{l}\text { Bilateral salpingo-oophorectomy } \\
\text { and excision of uterine remnant }\end{array}$ \\
\hline $\begin{array}{l}\text { HOO, et al. } \\
\text { (2016) [35] }\end{array}$ & 45 & Yes & LPT & US + MRI & $\begin{array}{c}15 \mathrm{~cm} \times 13 \mathrm{~cm} \times \\
13 \mathrm{~cm}\end{array}$ & Right adnexa & $\begin{array}{l}\text { Right salpingo-oophorectomy and } \\
\text { excision of uterine remnant }\end{array}$ \\
\hline $\begin{array}{l}\text { Case Described } \\
\text { by This Article }\end{array}$ & 50 & Yes & $\begin{array}{c}\text { LPT } \\
\text { Pfannenstiel }\end{array}$ & $\mathrm{US}+\mathrm{CT}$ & $\begin{array}{c}10 \mathrm{~cm} \times 9 \mathrm{~cm} \times \\
7 \mathrm{~cm}\end{array}$ & $\begin{array}{l}\text { Paraovarian } \\
\text { mass }\end{array}$ & Mass only \\
\hline
\end{tabular}

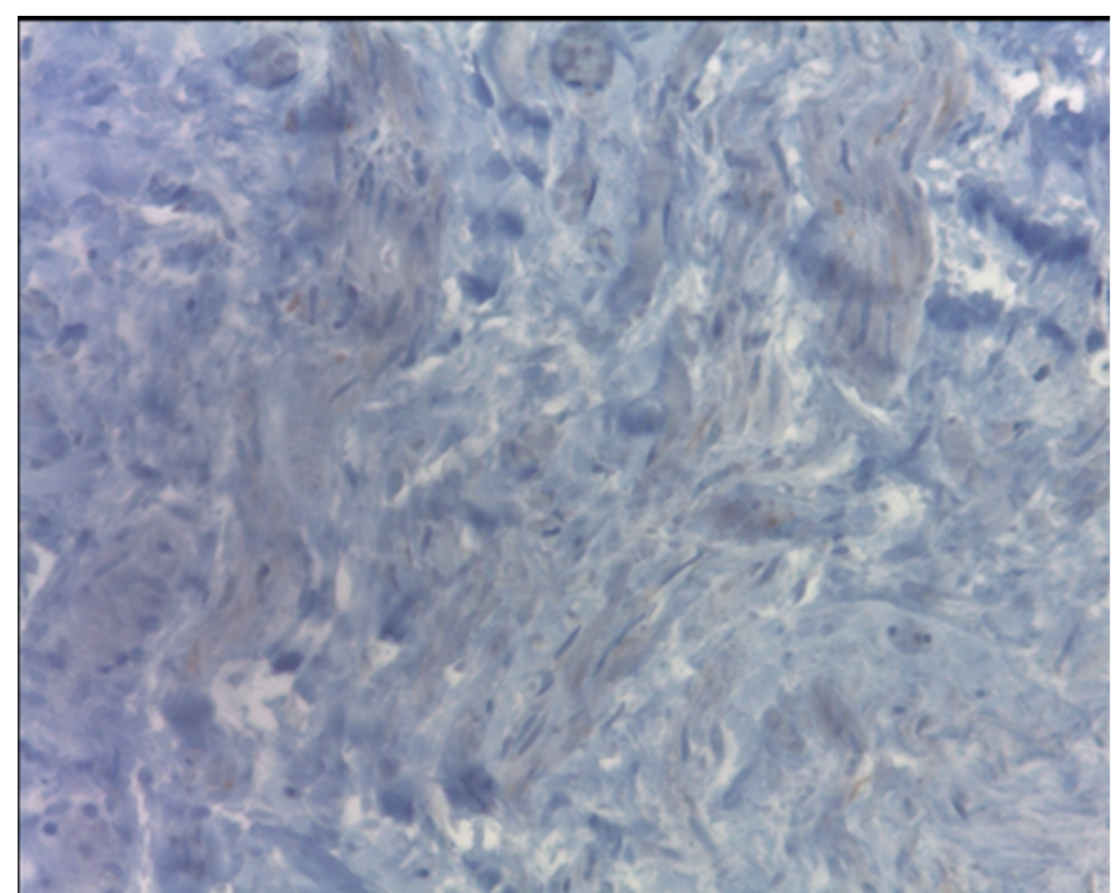

Figure 7. In the tissue, the presence of estrogenic receptors was negative.

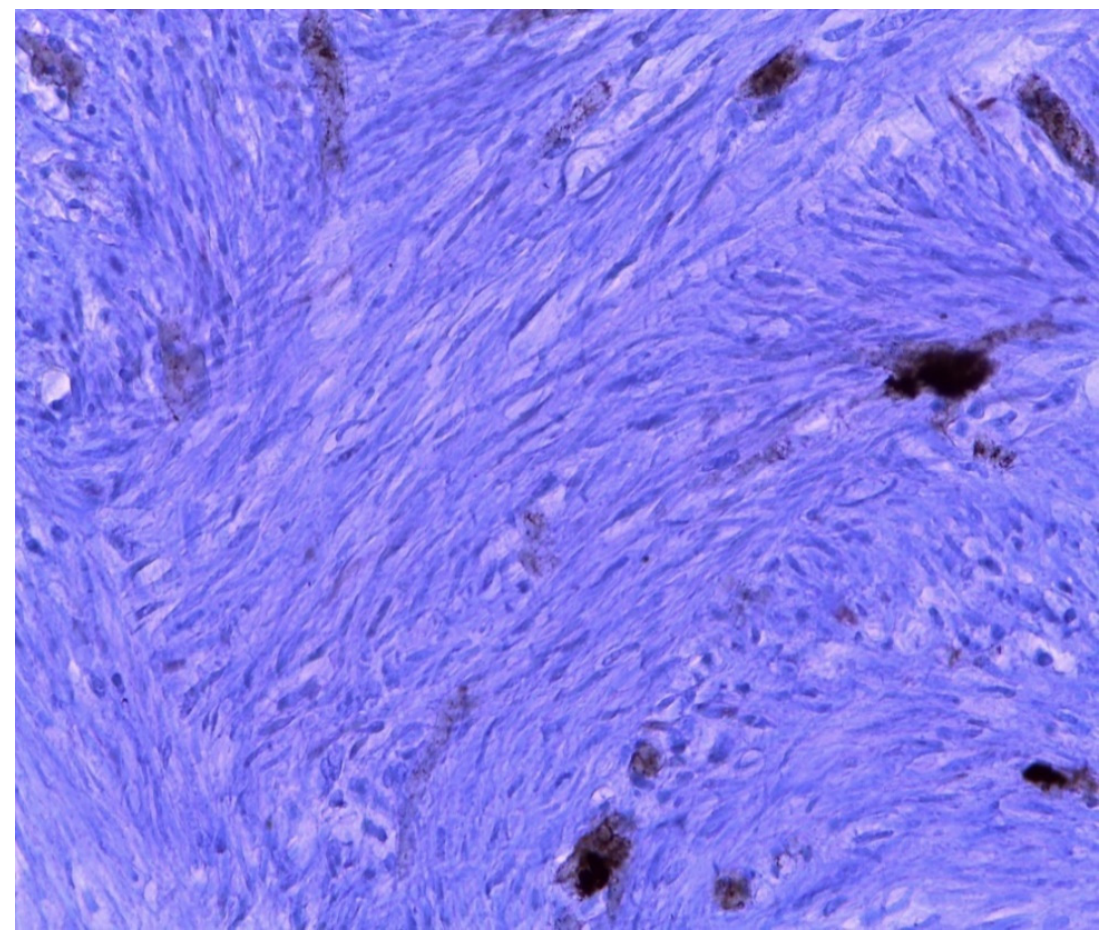

Figure 8. In the tissue, the presence of progestin receptors was negative. 


\section{Conclusions}

In women with Mayer-Rokitansky-Küster-Hauser syndrome presenting with pelvic pain not responsive to the analgesic therapy, the presence of a gynecological complication should always be considered among the possible diagnosis. The use of ultrasonography is recommended, adding a CT or an MRI for higher anatomical detail and better pre-surgical stadiation. However, the proper and final diagnosis, due to the rarity and the anatomical complexity of these lesions, can be given only through surgical procedure and histological evaluation.

We demonstrated that the etiopathogenesis of leiomyomas still remains unclear, and the cluster of agonists and antagonists with their receptors involved in the development needs to be clarified.

Finally, from our review, it emerges that the occurrence of new myomatous neoplasms in patients with $\mathrm{MRKH}$, starting or not from uterine rudiments, could cause an acute abdomen requiring urgent surgery. For this reason, patients who undergo pelvic surgery could benefit from preventive remotion of uterine residues by minimally invasive surgery with minimal discomfort to the patients.

Author Contributions: Conceptualization, F.R., G.R., G.M. and M.M.; methodology, G.R., S.C., G.S. and F.P.M.; software, S.C., G.S., G.M., M.M.; validation, G.R., F.R., A.R. and F.P.M.; formal analysis, S.C. and G.S.; investigation, G.M., S.C., G.S.; resources, G.M., A.R., M.M.; data curation, S.C., G.S., G.M.; writing—original draft preparation, S.C., G.S., G.M.; writing—review and editing, S.C., G.S., F.R. and G.S.; visualization, A.R. and F.P.M.; supervision, G.S. All authors have read and agreed to the published version of the manuscript.

Funding: This research received no external funding.

Institutional Review Board Statement: The study was conducted according to the guidelines of the Declaration of Helsinki and approved by the Institutional Review Board of the Institute for Maternal and Child Health, I.R.C.C.S. "Burlo Garofolo"-Trieste (RC 08/2020 February 2020).

Informed Consent Statement: Informed consent was obtained from all subjects involved in the study.

Data Availability Statement: The authors confirm that the data supporting the findings of this study are available within the article.

Conflicts of Interest: The authors declare no conflict of interest.

\section{References}

1. Choussein, S.; Nasioudis, D.; Schizas, D.; Economopoulos, K.P. Mullerian dysgenesis: A critical review of the literature. Arch. Gynecol. Obstet. 2017, 295, 1369-1381. [CrossRef]

2. Salem Wehbe, G.; Bitar, R.; Zreik, T.; Samaha, M.; Walter, C.; Sleiman, Z. Intra-peritoneal leiomyoma a of the round ligament in a patient with Mayer-Rokitansky-Küster-Hauser (MRKH) syndrome. Facts Views Vis. Obgyn 2016, 8, 233-2352. [PubMed]

3. Amaratunga, T.; Kirkpatrick, L.; Yan, Y.; Karlicki, F. Ectopic Pelvic Fibroid in a Woman with Uterine Agenesis and MayerRokitansky-Küster-Hauser Syndrome. Ultrasound Q. 2017, 33, 237-241. [CrossRef] [PubMed]

4. Papa, G.; Andreotti, M.; Giannubilo, S.R.; Cesari, R.; Ceré, I.; Tranquilli, A.L. Case report and surgical solution for a voluminous uterine leiomyoma in a woman with complicated Mayer-Rokitansky-Küster-Hauser syndrome. Fertil. Steril. 2008, 90, 2014.e52014.e6. [CrossRef]

5. Fletcher, H.M.; Campbell-Simpson, K.; Walcott, D.; Harriott, J. Müllerian remnant leiomyomas in women with Mayer-RokitanskyKüster-Hauser syndrome. Obstet Gynecol. 2012, 119 Pt 2, 483-485. [CrossRef]

6. Yan, C.M.; Mok, K.M. Uterine fibroids and adenomyosis in a woman with Rokitansky-Kuster-Hauser syndrome. J. Obstet. Gynaecol. 2002, 22, 561-574. [CrossRef]

7. Taylor, E.; Gomel, V. The uterus and fertility. Fertil. Steril. 2008, 89, 1-6. [CrossRef] [PubMed]

8. Van den Bosch, T.; Dueholm, M.; Leone, F.P.; Valentin, L.; Rasmussen, C.K.; Votino, A.; Van Schoubroeck, D.; Landolfo, C.; Installé, A.J.; Guerriero, S.; et al. Terms, definitions and measurements to describe sonographic features of myometrium and uterine masses: A consensus opinion from the Morphological Uterus Sonographic Assessment (MUSA) group. Ultrasound Obstet. Gynecol. 2015, 46, 284-298. [CrossRef]

9. Jokimaa, V.; Virtanen, J.; Kujari, H.; Ala-Nissilä, S.; Rantanen, V. A Mayer-Rokitansky-Kuster-Hauser patient with leiomyoma and dysplasia of neovagina: A case report. BMC Womens Health 2020, 20, 157. [CrossRef] 
10. Sharma, R.; Guleria, K.; Suneja, A.; Bhaskaran, S.; Tanveer, N. Giant leiomyoma with extensive myxoid degeneration in Mayer-Rokitansky-Küster-Hauser syndrome. Int. J. Gynecol. Obstet. 2017, 138, 125-127. [CrossRef]

11. Narayanan, R.; Mariappan, S.; Paulraj, S.; Shankar, B. Imaging of leiomyomas arising from Müllerian remnants in a case of Mayer-Rokitansky-Küster-Hauser syndrome. BMJ Case Rep. 2015. [CrossRef]

12. Park, J.W.; Hwang, D.W.; Jang, J.A.; Choi, Y.J.; Chun, K.C.; Kim, Y.A. Leiomyoma mimicking a pelvic tumour in Mayer-RokitanskyKüster-Hauser syndrome: A case report. J. Obstet. Gynaecol. 2016, 36, 279-280. [CrossRef]

13. Hasegawa, A.; Igarashi, H.; Ohta, T.; Kurachi, H.; Takahashi, K. Three-dimensional computed tomography of pelvic masses in Mayer-Rokitansky-Küster-Hauser syndrome. Obstet Gynecol. 2015, 125, 393-396. [CrossRef] [PubMed]

14. Chun, S.; Kim, Y.M.; Ji, Y.I. Uterine adenomyosis which developed from hypoplastic uterus in postmenopausal woman with mayer-rokitansky-kuster-hauser syndrome: A case report. J. Menopausal. Med. 2013, 19, 135-138. [CrossRef]

15. Jadoul, P.; Pirard, C.; Squifflet, J.; Smets, M.; Donnez, J. Pelvic mass in a woman with Mayer-Rokitansky-Kuster-Hauser syndrome. Fertil. Steril. 2004, 81, 203-204. [CrossRef]

16. Páez-López, G.; los Ríos-Posada, D.; Fernando, J.; Arango-Martínez, A.M.; Castañeda-Roldán, J.D.; Serna-Agudelo, E.; VásquezRuiz, R.; Almanza-Payares, L.A.; Calle-Gómez, G.A. Laparoscopic management of uterine myomatosis in a patient with rokitansky syndrome. case report and review of the literature. Rev. Colomb. Obs. Ginecol. 2013, 64, 469-474. [CrossRef]

17. Edmonds, D.K. Multiple fibroids in a postmenopausal woman with Mayer Rokitansky Kuster Hauser syndrome. J. Pediatr. Adolesc. Gynecol. 2003, 16, 65-66. [CrossRef]

18. Lamarca, M.; Navarro, R.; Ballesteros, M.E.; García-Aguirre, S.; Conte, M.P.; Duque, J.A. Leiomyomas in both uterine remnants in a woman with the Mayer-Rokitansky-Küster-Hauser syndrome. Fertil. Steril. 2009, 91, 931.e13-931.e15. [CrossRef]

19. Rawat, K.S.; Buxi, T.; Yadav, A.; Ghuman, S.S.; Dhawan, S. Large leiomyoma in a woman with Mayer-Rokitansky-Kuster-Hauser syndrome. J. Radiol. Case Rep. 2013, 7, 39-46. [CrossRef]

20. Deligeoroglou, E.; Kontoravdis, A.; Makrakis, E.; Christopoulos, P.; Kountouris, A.; Creatsas, G. Development of leiomyomas on the uterine remnants of two women with Mayer-Rokitansky-Küster-Hauser syndrome. Fertil. Steril. 2004, 81, 1385-1387. [CrossRef]

21. Kulkarni, M.M.; Deshmukh, S.D.; Hol, K.; Nene, N. A rare case of Mayer-Rokitansky-Kuster-Hauser syndrome with multiple leiomyomas in hypoplastic uterus. J. Hum. Reprod. Sci. 2015, 8, 242. [CrossRef]

22. Girma, W.; Woldeyes, W. Leiomyoma Arising from Mullerian Remnant, Mimicking Ovarian Tumor in a Woman with MRKH Syndrome and Unilateral Renal Agenesis. Ethiop. J. Health Sci. 2015, 25, 381-384. [CrossRef] [PubMed]

23. Dimitriadis, I.; Pagidas, K.; Vaughan, D.; Kim, Y.B. Mitotically Active Leiomyoma in a Woman with Mayer-Rokitansky-KüsterHauser Syndrome: A Case Report. J. Reprod. Med. 2016, 61, 299-301.

24. Karthik, S.D.S.; Mahey, R.; Kachhawa, G.; Kriplani, A. Laparoscopic management of leiomyoma arising from mullerian Remnant in Mayer-Rokitansky-Kuster-Hauser syndrome. J. Gynecolocic Surg. 2017, 38, 276-279. [CrossRef]

25. Harzif, A.K.; Ambalagen, S.; Charilda, F.E.; Mutia, H.D. A rare case of multiple leiomyomas on rudimentary uterus in a woman with Mayer Rokitansky Kuster Hauser (MRKH) syndrome: A challenging diagnosis and laparoscopic approach. Int. J. Surg. Case Rep. 2021, 81, 105711. [CrossRef]

26. Lanowska, M.; Favero, G.; Schneider, A.; Kholer, C. Laparoscopy for differential diagnosis of a pelvic mass in a patient with Mayer-Rokitanski-Kuster-Hauser (MRKH) syndrome. Fertil. Steril. 2009, 91, 931.e17-931.e18. [CrossRef]

27. Rhee, C.S.; Kim, J.S.; Woo, S.K.; Suh, S.J. MRI of Round ligament leiomyoma associated with Mayer-Rokitansky-Kuster-Huser syndrome. Abdom Imaging 1999, 24, 201-204. [CrossRef]

28. Tsin, D.A.; Waters, T.K.; Granato, R.C. Laparoscopic myomectomy in patient with Mayer-Rokitansky-Kuster-Hauser Syndrome. J. Am. Assoc. Gynecolocic Laparosc. 2000, 7, 411-413. [CrossRef]

29. Fukuda, J.; Kumazawa, Y.; Fujimoto, T.; Tanaka, T.J. Mayer-Rokitansky-Kustner Hauser syndrome complicated by either uterine leiomyoma or ovarian tumor. Obstet Gynaecol. Res. 2010, 36, 191-194. [CrossRef]

30. Albahlol, I.A.; Elshamy, M.; El-Hady, H.A.F.; Abd-Elwahab, E.M. Leiomyomas in a case of Mayer-Rokitansky-Kuster-Hauser syndrome: Case report. Eur. J. Obstet. Gynecol. 2019. [CrossRef]

31. Pati, S.; Mukhopadhyay, A. Leiomyoma in a young woman with Mayer-Rokitansky-Huster-Hauser syndrome. J. Indian Med. Assoc. 2009, 107, 460-461.

32. Vidyashree, P.G.; Muralidhar, P.V.; Jayaram, N.; Latha, K. Mayer-Rokitansky-Kuster-Hauser syndrome with multiple leiomyomas. Int. J. Gynecol. Obstet. 2015, 128, 270-271. [CrossRef]

33. Kundu, K.; Cohen, A.W.; Goldberg, J. Acute torsion of uterine remnant leiomyoma with Mayer-Rokitansky-Küster-Hauser syndrome. Fertil. Steril. 2014, 102, 607-609. [CrossRef]

34. Yi, S.; Xu, B.; Zeng, F.; Xue, M. Acute Torsion of Paraovarian Cyst and Ipsilateral Uterine Remnant Leiomyoma in a Patient with Mayer-Rokitansky-Küster-Hauser Syndrome. J. Minim. Invasive Gynecol. 2017, 24, 6-7. [CrossRef]

35. Hoo, P.S.; Norhaslinda, A.R.; Shah Reza, J.N. Case Report Rare Case of Leiomyoma and Adenomyosis in Mayer-RokitanskyKuster-Hauser Syndrome. Case Rep. Obstet. Gynecol. 2016, 2016, 3725043.

36. Petrić, A.; Stefanović, M.; Vukomanović, P.; Zivadinović, R.; Tubić, A.; Janjić, Z. Acute abdomen in a patient with MayerRokitansky-Kuster-Hauser syndrome. Vojn. Pregl. 2008, 65, 706-709. [CrossRef]

37. Galajdova, L.; Verbeken, K.; Dhont, M. Recurrent multiple leiomyomata in a patient with Mayer-Rokitansky-Küster-Hauser syndrome. J. Obstet. Gynaecol. 2003, 23, 448-449. [CrossRef] 
38. Stabile, G.; Zinicola, G.; Romano, F.; Buonomo, F.; Mangino, F.P.; Ricci, G. Management of Non-Tubal Ectopic Pregnancies: A Single Center Experience. Diagnostics 2020, 10, 652. [CrossRef]

39. Stewart, E.A.; Laughlin-Tommaso, S.K.; Catherino, W.H.; Lalitkumar, S.; Gupta, D.; Vollenhoven, B. Uterine fibroids. Nat. Rev. Dis. Primers. 2016, 2, 16043. [CrossRef]

40. Ura, B.; Monasta, L.; Arrigoni, G.; Battisti, I.; Licastro, D.; Di Lorenzo, G.; Romano, F.; Aloisio, M.; Peterlunger, I.; Stabile, G.; et al. Phosphoproteins Involved in the Inhibition of Apoptosis and in Cell Survival in the Leiomyoma. J. Clin. Med. 2019, 8, 691. [CrossRef] [PubMed]

41. Ura, B.; Monasta, L.; De Spelorzi, Y.C.C.; Arrigoni, G.; Franchin, C.; Biffi, S.; Aloisio, M.; Gaita, B.; Licastro, D.; Athanasakis, E.; et al. Proteins involved in oxidative stress in leiomyoma tissues treated with ulipristal acetate. Mol. Med. Rep. 2021, 23, 1. [CrossRef] [PubMed] 